\title{
The interference of methods in the collection of teredinids (Mollusca, Bivalvia) in mangrove habitats
}

\author{
Rosa M. V. Leonel'; Sônia G. B. C. Lopes²; Daniela T. de Moraes² \& Marcos Aversari1 $^{1}$ \\ 1. Departamento de Sistemática e Ecologia, Centro de Ciências Exatas e da Natureza, Universidade Federal da Paraíba, 58059-900 \\ João Pessoa, PB, Brasil. \\ 2. Departamento de Zoologia, Instituto de Biociências, Universidade de São Paulo, 05422-970 São Paulo, SP, Brasil. \\ (sonialop@uol.com.br)
}

\begin{abstract}
In the estuary of the Mamanguape River (Paraíba, Brazil), a new collection technique was developed and applied with virgin poles of mangrove trees Avicennia schaueriana (Verbenaceae), Rhizophora mangle (Rhizophoraceae), and Laguncularia racemosa (Combretaceae), taking into account wood preference, water salinity and depth influence during teredinid larval settlement. Sets of poles were vertically fixed in the riverbed at three sites along a decreasing salinity gradient, where they stayed for four months. The poles were collected and divided into upper, median, and lower segments, in agreement with different immersion regimes. An increase of $239 \%$ was obtained in the number of individuals when compared to a previous study in the same area using a different methodology. The species Teredo bartschi (Clapp, 1923), Nausitora fusticula (Jeffreys, 1860 ) and Bankia fimbriatula Moll \& Roch, 1931 were registered in both studies, and the species Psiloteredo healdi (Bartsch, 1931 ) is here registered for the first time as occurring in that estuary. The species Neoteredo reynei (Bartsch, 1920), previously registered on tree branches of the mangrove habitat, was not found in the present work. Bankia fimbriatula, the most abundant species, did not show preference for any substratum but occurred significantly on the lower segment of the poles. N. fusticula, second in abundance, preferred to settle on poles of A. schaueriana and on any of the three segments. Aiming to assess the habitat variations, a more accurate study on teredinids diversity in mangrove ecosystems should be performed through a concomitant analysis from tree branches of the mangrove habitat, as well as from poles of mangrove trees or panels made of pine wood or mangrove trees wood. These collection devices should be maintained along a decreasing salinity gradient exposed to different tide levels.
\end{abstract}

KEYWORDS. Wood-boring bivalves, wood preference, new collection technique.

RESUMO. Interferência de métodos na coleta de teredinídios (Mollusca, Bivalvia) em habitats de manguezais. Contemplando a preferência pelo tipo de madeira, a influência da profundidade e da salinidade durante assentamento larval de teredinídeos, uma nova técnica de coleta foi aplicada e desenvolvida no estuário do rio Mamanguape (Paraíba, Brasil), utilizando varas virgens de três espécies de árvores do manguezal: Avicennia schaueriana (Verbenaceae), Rhizophora mangle (Rhizophoraceae) e Laguncularia racemosa (Combretaceae). Em três estações demarcadas ao longo do gradiente decrescente de salinidade, conjuntos de varas foram verticalmente fixados nas margens do rio. Após quatro meses, as varas eram coletadas e divididas em três segmentos (superior, médio e inferior), de acordo com os regimes de imersão a que foram submetidas. Comparativamente aos dados obtidos por um estudo anterior na mesma área, com outras metodologias de coleta, foi obtido um aumento de $239 \%$ no número de indivíduos coletados com a nova técnica. Embora as espécies Teredo bartschi (Clapp, 1923), Nausitora fusticula (Jeffreys, 1860) e Bankia fimbriatula Moll \& Roch, 1931 tenham ocorrido nos dois estudos, o teredinídeo Psiloteredo healdi (Bartsch, 1931) tem sua presença registrada pela primeira vez neste estuário. Tendo sido previamente registrada em ramos de árvores do manguezal, Neoteredo reynei (Bartsch, 1920) não foi coletada no presente trabalho. Sendo a espécie mais abundante, $B$. fimbriatula não mostrou preferência de assentamento em nenhum dos substratos, ocorrendo significativamente associada ao segmento inferior das varas. Como segunda espécie mais abundante, $N$. fusticula mostrou preferência significativa de assentamento em A. schaueriana, ocorrendo indistintamente nos três segmentos das varas. Visando contemplar as variações do habitat e obter maior precisão de resultados, é recomendável que em estudos sobre a diversidade de teredinídeos, sejam incluídas análises concomitantes de troncos e ramos das árvores, com o uso de varas de árvores do manguezal ou de coletores artificiais feitos com pinho ou madeira de árvores do manguezal. Os coletores devem ser mantidos ao longo do gradiente de salinidade e expostos aos diferentes níveis das marés.

PALAVRAS-CHAVE. Bivalves perfurantes de madeira, preferência pelo tipo de madeira, nova técnica de coleta.

The presence of wood in estuarine and marine waters provides essential stimulus for settlement of planktonic larvae of teredinids. After settling on wood surface, the larvae metamorphose and bore into wood substratum, where they develop and spend their whole adult life inside burrows (TURNER, 1966).

Collections of wood-boring species in Brazilian estuaries have been carried out through different methodologies by using (1) laminated panels of pine wood sheets (JUNQUEIRA et al., 1989), (2) branches from mangrove trees (Lopes \& NARCHI, 1993; ReIS, 1995), (3) the first two methods combined (MÜLLER \& LANA, 1986;
LEONEL et al., 2002), (4) laminated panels of pine wood and of mangrove tree sheets combined with entire blocks of wood of mangrove trees (LOPES \& NARCHI, 1997), and (5) entire blocks of wood from mangrove trees (SANTOS et al., 2003).

Comparing the results from these surveys, it was observed that, despite a greater collection effort, the analysis of tree branches has generated larger number of species and specimens. Among possible factors interfering in these results, it can be considered differences in the time of water exposition by the wood since the penetration of teredinid larvae in the wood 
depends on the time of immersion and formation of biofilm on the wood (Miller, 1926; Owen, 1953; Gara et al., 1997; LoPES \& NARCHI, 1997). Other factors also seem to interfere, as water salinity and pollution (HoAgland, 1986; Lopes \& NARChI, 1993), presence of fouling organisms on the wood surface (JUNQUEIRA et al., 1989), presence of wood borers (Southwell \& Bultman, 1971; Hoagland, 1986; Gara et al., 1997) and wood type (Southwell \& Bultman, 1971; Reis, 1995).

In a study performed throughout one year in the Mamanguape River by LEONEL et al. (2002) with woodboring bivalves in native tree branches (Avicennia schaueriana, Rhizophora mangle and Laguncularia racemosa) and in submerged (1 $\mathrm{m}$ depth) pine wood panels, it was reported the teredinids species Teredo bartschi (Clapp, 1923), Nausitora fusticula (Jeffreys, 1860), Bankia fimbriatula Moll \& Roch, 1931 and Neoteredo reynei (Bartsch, 1920) and a total of 368 specimens. These numbers of species and individuals were lower than the ones obtained throughout one year from Brazilian Southeastern estuary (Lopes \& NARCHI, 1993; 1997). An analysis of the methodology adopted by LEONEL et al. (2002) suggests that their results were influenced by differences in the larval penetration into the wood of the mangrove trees and the period the substratum was submerged. In order to investigate these suppositions a new collection technique was tested, considering a greater sampling effort to analyze the larvae preference for wood type and the influence of water salinity and depth on the larval settlement.

\section{MATERIAL AND METHODS}

The Mamanguape River is located in the State of Paraíba, Northeastern Brazil, in a governmental protected area of $c a$. 6000 ha. It presents on both riversides a typical mangrove vegetation constituted by Avicennia schaueriana (Verbenaceae), Rhizophora mangle (Rhizophoraceae), and Laguncularia racemosa (Combretaceae). The climate is typical of the Northeastern Brazilian littoral, characterized by a dry period (from March to August), with a minimum and maximum temperature of $24^{\circ} \mathrm{C}$ and $36^{\circ} \mathrm{C}$, respectively, and a mean annual rainfall higher than $1250 \mathrm{~mm}$ (NIMER, 1977).

Three collection stations were demarcated along the right riverside of the Mamanguape River: station I $\left(6^{\circ} 45^{\prime} 49^{\prime} \mathrm{S} ; 34^{\circ} 57^{\prime} 07^{\prime} \mathrm{W}\right)$, close to Tramatáia village and to the river mouth; station II $\left(6^{\circ} 47^{\prime} 07^{\prime \prime} \mathrm{S}\right.$; $\left.34^{\circ} 58^{\prime} 44^{\prime \prime} \mathrm{W}\right)$, in the intermediate position; and station III ( $6^{\circ} 47^{\prime} 28^{\prime}$ 'S; $34^{\circ} 59^{\prime} 50^{\prime}$ 'W), located upstream the river course at $12 \mathrm{~km}$ distant from station I. The station I was positioned $2 \mathrm{~km}$ downstream of its previous position demarcated by LeONEL et al. (2002), and the other two stations were maintained in the same range of the previous study.

Teredinids were collected by using virgin poles ca. $2.5 \mathrm{~m}$ long of tree species (A. schaueriana, $R$. mangle, and L. racemosa) collected from the inner edges of mangrove habitat. After being cut off, the poles were air-dried during three months before use. Between February and August 2000 five poles from each tree species were monthly distributed at each station, totalling 105 poles from each tree species. At the low tide, each pole was vertically fixed in the riverbed, being $c a .70 \mathrm{~cm}$ buried into the substratum. The day and month of installation and the name of the tree species were engraved on PVC labels tied with brass wire to each pole. During high tides the poles became totally recovered by water at all stations ( maximum syzygyal tide $=2.6 \mathrm{~m}$ ).

After four months, the submerged poles were collected. Due to high infestation of barnacles (Balanus improvisus Darwin) and the absence of Teredinidae specimen on the pole free end, this segment (ca. 20 $\mathrm{cm}$ ) was cut off and excluded of our estimations. From this point downwards, the poles were cut in three segments (upper, median and lower) with $55 \mathrm{~cm}$ in length each. The upper segment was totally exposed to air during low tides, the lower segment was permanently submerged in the water and the median segment was partly air exposed during low tides.

The collected segments were kept in aquaria at a salinity of 25 psu until the removal of the wood-borers using chisels, hammer and nippers. The collected specimens were preserved in alcohol (85\%) plus commercial glycerin $(5: 1)$.

The identification of specimens was based on the structure of the pallets, according to TURNER (1966; 1971). The number of specimens identified was counted and classified according to its localization at each segment of the pole from each tree species at each station. The length of individuals belonging to the most numerous species was measured by using a calliper accurate to nearest $0.1 \mathrm{~mm}$.

The collected and identified specimens were deposited in the Collection of Marine Invertebrates Paulo Young (CIMPY) at the Department of Sistematics and Ecology of the Universidade Federal da Paraíba with the following register numbers: Nausitora fusticula (Jeffreys, 1860) - 1745 and 1746; Bankia fimbriatula Moll \& Roch, 1931 - 1747 and 1748; Teredo bartschi (Clapp, 1923) - 1749; and Psiloteredo healdi (Bartsch, 1931) - 1750.

In order to observe the preference of the most abundant species for any of the tree species and for specific segment of the pole, it was applied a chisquare test $\left(x^{2} ; \mathrm{p}<0.01\right)$.

The water salinity and temperature of water surface during low tides were recorded throughout the year by using a refractometer and a mercury thermometer, respectively.

\section{RESULTS}

It was analyzed 544 segments (upper, median, and lower) of the poles from the species of the mangrove trees (Tab. I), corresponding to $57.6 \%$ of total expected segments $(\mathrm{N}=945)$. This percentage resulted from partial or total loss of poles due to a large amount of sediment carried during the rainy period that burried them and to poles lost or broken 
during collection.

Four species of Teredinidae were collected: Teredo bartschi, Psiloteredo healdi, Nausitora fusticula, and Bankia fimbriatula. The dominant species were $B$. fimbriatula with 726 individuals and $N$. fusticula with 142 individuals (Tab. II).

Considering all the Teredinidae species, $46.6 \%$ of their larvae penetrated into poles of $A$. schaueriana, $34.2 \%$ into poles of $R$. mangle and $19.2 \%$ into poles of $L$. racemosa (Tab. II). Nausitora fusticula showed a significant preference to bore into $A$. schaueriana $\left(x^{2}=42.52 ; \mathrm{df}=2 ; \mathrm{p}<0.01\right)$ in $70.4 \%$ of the cases, whereas $B$. fimbriatula did not show preference $(\mathrm{p}>0.05)$ to any tree and occurred evenly associated to A. schaueriana (38.4\%) and to $R$. mangle (41.5\%) and less to L. racemosa (20.1\%) (Tab. II). With low numerical expressiveness, $T$. bartsch $i$ was associated especially to $R$. mangle and $A$. schaueriana, and $P$. healdi to $L$. racemosa and $A$. schaueriana (Tab. II). Specimens of $B$. fimbriatula and

Table I. Total number of upper, median and lower segments analyzed in poles of the mangrove trees Rhizophora mangle, Avicennia schaueriana and Laguncularia racemosa, fixed vertically in the Mamanguape River riverbed.

\begin{tabular}{lcccc}
\hline Segment & $\begin{array}{c}\text { Rhizophora } \\
\text { mangle }\end{array}$ & $\begin{array}{c}\text { Avicennia } \\
\text { schaueriana }\end{array}$ & $\begin{array}{c}\text { Laguncularia } \\
\text { racemosa }\end{array}$ & Total \\
\hline Upper & 68 & 56 & 61 & 185 \\
Median & 69 & 56 & 61 & 186 \\
Lower & 66 & 56 & 51 & 173 \\
Total & 203 & 168 & 173 & 544 \\
\hline
\end{tabular}

$N$. fusticula occurred on poles at all three stations. However, specimens of $T$. bartsch $i$ were restricted to station I and those of $P$. heald $i$ were present only on stations II and III (Tab. II).

When considering the attachment preference for the pole segments, in $57.6 \%$ of the cases $B$. fimbriatula had highly significant occurrence $\left(x^{2}=53.10 ; \mathrm{df}=2 ; \mathrm{p}<0.01\right)$ on the lower segment from all trees (Tab. III). Specimens of $N$. fusticula were not significantly $(\mathrm{p}>0.5)$ related to any of the pole segments.

Salinity of the superficial water in the estuary showed seasonal variation associated to the rainy period (April to September 2000) and to the dryer one (October to December 2000) (Fig. 1) with an annual variation from 0.3 to $33 \mathrm{psu}$. The highest salinity values occurred at station I (between 0.5 and $33 \mathrm{psu}$ ), followed by station II (between 0.0 and $28 \mathrm{psu}$ ) and III (between 0.0 and $26 \mathrm{psu})$.

Water temperature was relatively constant throughout the year, with annual mean values of $28.3^{\circ} \mathrm{C}$ $( \pm 1.4)$ and lowest value of $24.75^{\circ} \mathrm{C}$ in July.

Wood-boring specimens were more abundant during the rainy period between June and August 2000, and less abundant during the dry one, between September and December 2000 (Fig. 2).

The body length of the specimens varied from 0.5 to $11.9 \mathrm{~cm}$ in B. fimbriatula and 0.7 to $11.2 \mathrm{~cm}$ in $N$. fusticula (Fig. 3). The largest number of specimens of $B$. fimbriatula $(42 \%)$ occurred in the size range $2.1-4.0 \mathrm{~cm}$, and of $N$. fusticula (34\%) in two size ranges: $0.1-2.0 \mathrm{~cm}$ and $2.1-4.0 \mathrm{~cm}$ (Fig. 3).

Table II. Total number and percentage of specimens of teredinids collected at stations I, II, and III, in poles of the mangrove trees Rhizophora mangle, Avicennia schaueriana and Laguncularia racemosa, from July to December 2000, in the Mamanguape River.

\begin{tabular}{|c|c|c|c|c|c|c|c|c|c|c|c|}
\hline \multirow[t]{2}{*}{ Species } & & \multicolumn{3}{|c|}{$\begin{array}{l}\text { Rhizophora } \\
\text { mangle }\end{array}$} & \multicolumn{3}{|c|}{$\begin{array}{c}\text { Avicennia } \\
\text { schaueriana }\end{array}$} & \multicolumn{3}{|c|}{$\begin{array}{c}\text { Laguncularia } \\
\text { racemosa }\end{array}$} & \multirow[t]{2}{*}{ Total } \\
\hline & & $\mathrm{I}$ & II & III & $\mathrm{I}$ & II & III & I & II & III & \\
\hline Bankia fimbriatula & $\begin{array}{l}\mathrm{N} \\
\%\end{array}$ & 111 & $\begin{array}{c}130 \\
38.4\end{array}$ & 38 & 146 & $\begin{array}{r}102 \\
41.5\end{array}$ & 53 & 50 & $\begin{array}{c}81 \\
20.1\end{array}$ & 15 & 726 \\
\hline Nausitora fusticula & $\begin{array}{l}\mathrm{N} \\
\%\end{array}$ & 3 & $\begin{array}{c}9 \\
14.8\end{array}$ & 9 & 6 & $\begin{array}{c}44 \\
70.4\end{array}$ & 50 & 0 & $\begin{array}{c}9 \\
14.8\end{array}$ & 12 & 142 \\
\hline Teredo bartschi & $\begin{array}{l}\mathrm{N} \\
\%\end{array}$ & 1 & $\begin{array}{c}0 \\
16.7\end{array}$ & 0 & 5 & $\begin{array}{c}0 \\
83.3\end{array}$ & 0 & 0 & $\begin{array}{l}0 \\
0\end{array}$ & 0 & 6 \\
\hline Psiloteredo healdi & $\begin{array}{l}\mathrm{N} \\
\%\end{array}$ & 0 & $\begin{array}{l}0 \\
0\end{array}$ & 0 & 0 & $\begin{array}{c}1 \\
60.0\end{array}$ & 2 & 0 & $\begin{array}{c}2 \\
40.0\end{array}$ & 0 & 5 \\
\hline Total & $\begin{array}{l}\mathrm{N} \\
\%\end{array}$ & & $\begin{array}{l}301 \\
34.2\end{array}$ & & & $\begin{array}{l}410 \\
46.6\end{array}$ & & & $\begin{array}{r}169 \\
19.2\end{array}$ & & $\begin{array}{l}879 \\
100\end{array}$ \\
\hline
\end{tabular}

Table III. Total number and percentage of specimens of B. fimbriatula and N. fusticula, collected from the upper, median, and lower segments of poles of the mangrove trees Avicennia schaueriana (AS) and Laguncularia racemosa (LR), Rhizophora mangle (RM), in the Mamanguape River.

\begin{tabular}{|c|c|c|c|c|c|c|c|c|c|c|}
\hline \multirow[t]{3}{*}{ Species } & & \multicolumn{9}{|c|}{ Segment } \\
\hline & & \multicolumn{3}{|c|}{ Upper } & \multicolumn{3}{|c|}{ Median } & \multicolumn{3}{|c|}{ Lower } \\
\hline & & $\mathrm{RM}$ & AS & LR & $\mathrm{RM}$ & AS & LR & $\mathrm{RM}$ & AS & LR \\
\hline Bankia fimbriatula & $\begin{array}{l}\mathrm{N} \\
\%\end{array}$ & 40 & $\begin{array}{c}42 \\
17.3\end{array}$ & 44 & 79 & $\begin{array}{c}72 \\
25.1\end{array}$ & 31 & 160 & $\begin{array}{c}187 \\
57.6\end{array}$ & 71 \\
\hline Nausitora fusticula & $\begin{array}{l}\mathrm{N} \\
\%\end{array}$ & 8 & $\begin{array}{c}36 \\
38.7\end{array}$ & 11 & 6 & $\begin{array}{c}36 \\
35.2\end{array}$ & 8 & 7 & $\begin{array}{c}28 \\
26.1\end{array}$ & 2 \\
\hline
\end{tabular}



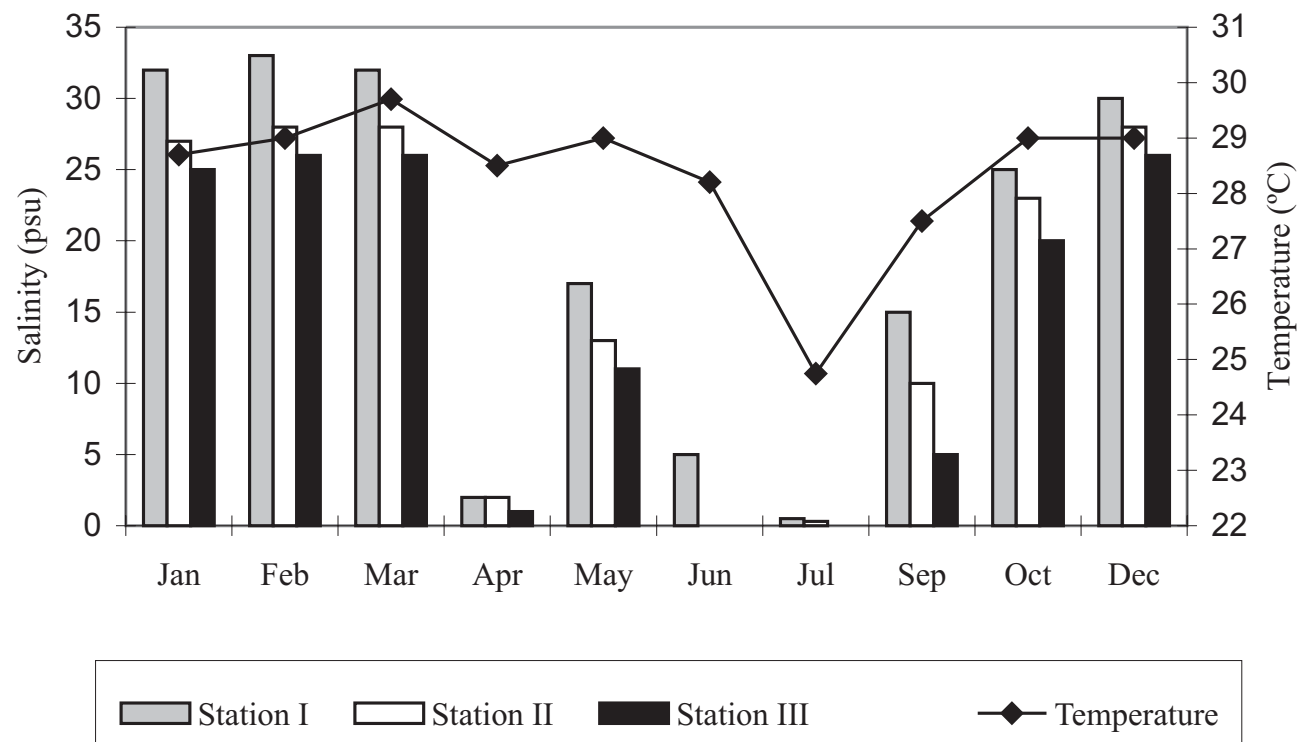

Fig. 1. Values of salinity and water temperature at collection stations I, II, and III in the Mamanguape River, from January to December 2000 .

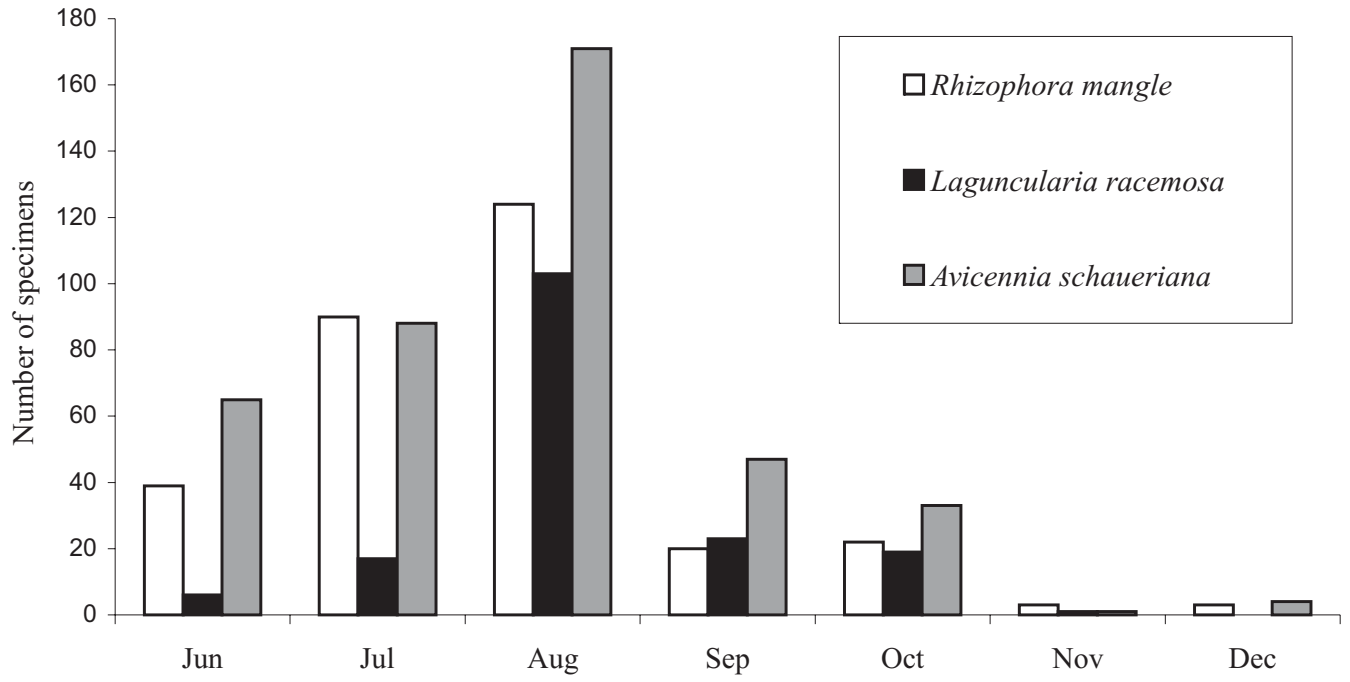

Fig. 2. Total number of specimens of teredinids collected from poles of the mangrove trees Rhizophora mangle, Avicennia schaueriana and Laguncularia racemosa, at all collection stations of the Mamanguape river, from June to December 2000.

Bankia fimbriatula

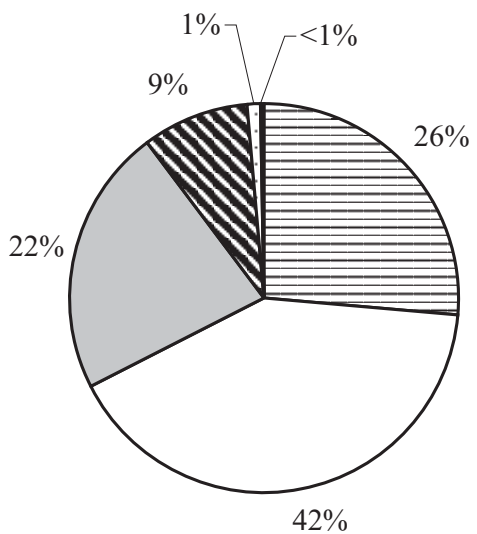

Nausitora fusticula

\begin{tabular}{|l} 
目0.1-2.0 cm \\
$\square 2.1-4.0 \mathrm{~cm}$ \\
$\square 4.1-6.0 \mathrm{~cm}$ \\
$\mathbf{\nabla} 6.1-8.0 \mathrm{~cm}$ \\
$\square 8.1-10.0 \mathrm{~cm}$ \\
$\square 10.1-12.0 \mathrm{~cm}$
\end{tabular}

$3 \% \quad 1 \%$

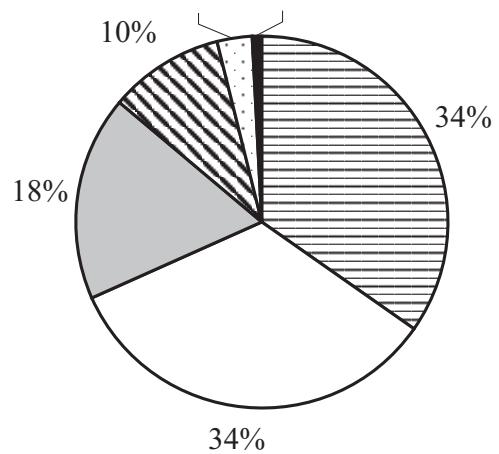

Fig. 3. Percentage of specimens of Nausitora fusticula $(\mathrm{N}=130)$ and of Bankia fimbriatula $(\mathrm{N}=414)$, per size class. 


\section{DISCUSSION}

A comparison of the present results with the ones obtained by LeONEL et al. (2002) in the Mamanguape River showed an increase of $239 \%$ of individuals collected and confirm their data with respect to the predominance of $B$. fimbriatula and $N$. fusticula, as well as the low numerical expressivity of T. bartschi and $N$. reynei. On the other hand, the distribution of the teredinids along the estuary are similar only for $B$. fimbriatula and $N$. fusticula. Teredo bartschi, which had been formerly registered throughout the entire estuary, occurred uniquely at station I and $P$. healdi, which was not registered in the previous work, was found exclusively at the stations II and III. This latter species is here registered for the first time to the Paraíba State and its occurrence in low salinities waters confirm the data reported by TURNER (1966), LoPES \& NARCHI (1993) and ReIS (1995).

The largest number of teredinid specimens were collected in August 2000 and it might indicate a greater reproduction activity after strong reduction of salinity, as shown by the results obtained from April to July 2000 .

The gradual reduction of the number of $B$. fimbriatula specimens from the lower towards the upper segment of the poles indicates that the exposure degree to water interfered on the larvae settlement of this species. As the lower segment was continually submerged, it represented a substratum with the highest probability to be settled and penetrated by larvae. The increase of larval recruitment of teredinids related to water depth is well known in brackish waters (MILLER, 1926; GREENFIELD, 1952; Schetelma \& Truit, 1954). When considering the lowest water level, GARA et al. (1997) reported that the least settlement of Bankia setacea (Tryon, 1863) occurred in a range from 0.6 to $-1.2 \mathrm{~m}$ and increased gradually up to $5.0 \mathrm{~m}$ depth at the bottom of the estuarine river. According to GREENFIELD (1952), in brackish waters the highest concentration of larvae near the bottom would have resulted from their sinking, due to their larger specific gravity in relation to freshwater surface. Despite the influence of all these events in explaining the different infestation levels of $B$. fimbriatula, these aspects would not justify the settlement of $N$. fusticula here observed. The competition for space with $B$. fimbriatula may have been the greatest interference factor of the undifferentiated penetration of $N$. fusticula in each pole segment. Taking the preference of $N$. fusticula for A. schaueriana as a reference, it was noticed that also on this tree the highest level of B. fimbriatula infestation reached a value 6.7 times higher than $N$. fusticula infestation value on the lower segment of this tree.

The occurrence of $N$. fusticula and B. fimbriatula according to the degree of immersion of each segment, makes clear the specific differences of tolerance of the animals to air exposure. This observation is corroborated by LOPES \& NARCHI (1993), who showed that in a mangrove habitat there is a zonal distribution of these species, according to the immersion degree during high tides. For those authors, $N$. fusticula occurred mostly in areas less frequently covered by water, whereas the opposite occurred with $B$. fimbriatula.

The high density of barnacles on the free end of the poles interfered on the installation of the Teredinidae larvae and no young or adult specimen were found in these section. These segments were not considered in the present paper. Nevertheless, it was observed some barnacles on the other segments of the poles, but their sparse fixation did not interfere on teredinids penetration into the wood.

The presence of specimens of $N$. fusticula and $B$. fimbriatula of different sizes indicates continual recruitment and settlement of their larval population throughout the period of observations. According to $N$. fusticula growth rates estimated by LOPES \& NARCHI (1997), specimens above $8.0 \mathrm{~cm}$ length penetrated into wood immediately after the pole contact with water.

Analyzing the resistance of more than a hundred of wood types to penetration of wood-boring molluscs, Southwell \& Bultman (1971) reported that hard wood trees with high specific gravity, low silica content, and oiled-wood, are resistant to penetration of teredinids. No difference in the teredinids degree of infestation was observed by SOUTHWEll \& Bultman (1971) on Avicennia marina, $R$. mangle, and L. racemosa, despite the lower infestation in the latter. Considering the lack of information on wood composition of the trees used in the present study, it is hypothesized here that the highest infestation of A. schaueriana by teredinids is related to its low hardness, once this wood was less resistant to opening for the animal removal. It is also considered that the high degree of infestation and the absence of preference of $B$. fimbriatula for wood from any of the tree species here analyzed, suggest that this teredinid is the most well adapted and aggressive species to infest mangrove wood substrata at the estuary of the Mamanguape River.

The continuous occurrence and high infestation of B. fimbriatula and $N$. fusticula is an indication that these species might have interfered on settlement and penetration of larvae of $T$. bartschi in the poles, since this species prefers to settle on virgin wood, as suggested by HoAgland (1986).

The absence of Neoteredo reynei in the poles of the present study probably resulted from its low incidence in the mangrove trees of the Mamanguape River, where LEONEL et al. (2002) estimated its relative frequency in $1.3 \%$.

Except for T. bartschi, a larviparous species (TuRNER \& JoHNSON, 1971), the other teredinid species in the estuary of the Mamanguape River are oviparous. According to TURNER (1984), when larviparous teredinid species are present in an area, they are the most abundant ones, due to their successful reproduction related to a shorter planktonic lifespan and a shorter period of exposure to the environmental variations than the oviparous species. Therefore, it should be expected a greater abundance of $T$. bartschi in the Mamanguape mangrove. However, it was not confirmed neither in the present study nor by LEONEL et al. (2002). The range of salinity tolerance of $T$. bartschi is from 6 to $35 \mathrm{psu}$, and its growth and activity are reduced in salinities below 10 psu (Hoagland, 1986). Thus, the low salinity values registered at all collection stations can be another cause of the low representativeness of T. bartschi in the area, besides its preference to bore into virgin wood. In other 
Brazilian estuary, LOPES \& NARCHI (1993) also obtained small number of individuals of the larviparous teredinid species Lyrodus floridanus (Bartsch, 1922), considering that the predominance of oviparous species may be related to the larval adaptation to environmental variations and not to the type of reproduction.

The results here obtained corroborate the literature, showing that the capacity of settlement of the teredinids larvae may be influenced by the exposition period to water by the wood, the type of wood and the water depth.

To accomplish the variations of habitat and the factors mentioned above, it is recommended during qualitative and quantitative studies of these bivalves in estuaries, to use pine or mangrove tree wood collectors and simultaneously branches of mangrove trees. The collectors must be installed along the salinity gradient and at different tidal levels.

Acknowledgments. This work is part of the Biodiversity Project of the Environmental Protection Area of the Mamanguape River, supported by $\mathrm{CNPq}$. We are grateful to Dr. Paulo Sechin Young in memorian, Museu Nacional do Rio de Janeiro, for the identification of barnacles; to Dr. Malva Isabel Medina Hernandez, Departamento de Sistemática e Ecologia, Universidade Federal da Paraíba, for her helpful assistance with statistics; and to Mr. Altino Figueiredo da Silva and Mr. Manoel Florêncio da Paz for their inestimable help during field work. We are also grateful to Dr. Breno Grisi for his helpful comments and translation of the manuscript into English.

\section{REFERENCES}

Gara, R. I.; Greulich, F. E. \& Ripley, K. L. 1997. Shipworm (Bankia setacea) host selection habits at the Port of Everett, Washington. Estuaries 20(2):441-449.

Greenfield, L. J. 1952. The distribution of marine borers in the Miami area in relation to ecological conditions. Bulletin of Marine Science Gulf and Caribbean 2(2):448-464.

HoAgland, K. E. 1986. Effects of temperature, salinity and substratum on larvae of the shipworms Teredo bartschi Clapp and T. navalis Linnaeus (Bivalvia: Teredinidae). American Malacological Bulletin 4(1):89-99.

Junqueira, A. O. R.; Silva, S. H. G. \& Silva, M. J. 1989. Avaliação da infestação e diversidade de Teredinidae (Mollusca-Bivalvia) ao longo da costa do Estado do Rio de Janeiro, Brasil. Memórias do Instituto Oswaldo Cruz 84:275-280.

Leonel, R. M. V.; Lopes, S. G. B. C. \& Aversari, M. 2002.
Distribution of wood-bivalves in the Mamanguape River estuary, Paraíba, Brazil. Journal of the Marine Biological Association of the United Kingdom 82:1039-1040.

Lopes, S. G. B. C. \& NARChI, W. 1993. Levantamento e distribuição das espécies de Teredinidae (Mollusca-Bivalvia) no manguezal da praia Dura, Ubatuba, São Paulo, Brasil. Boletim do Instituto Oceanográfico 41(1/2):29-38.

1997. Recrutamento larval e crescimento de Teredinidae (Mollusca-Bivalvia) em região entremarés de manguezais. Revista Brasileira de Oceanografia 45(1/2):77-88.

Miller, R. C. 1926. Ecological relations of marine wood-boring organisms in San Francisco bay. Ecology 7(3):247-254.

Müller, A. C. P. \& Lana, P. C. 1986. Teredinidae (Mollusca, Bivalvia) do litoral do Paraná, Brasil. Neritica 1(3):1-147.

Nimer, E. 1977. Clima. In: Goldemberg, C. ed. Geografia do Brasil. Região Nordeste. Rio de Janeiro, Sergraf-IBGE. v. 2, p.47-84

Owen, G. 1953. Vertical distribution of Teredo norvegica. Nature 171:484-485.

ReIs, R. E. M. L. 1995. Moluscos perfuradores de madeira do estado do Pará, Brasil: caracterização taxonômica, distribuição e resistência de madeiras. Boletim do Museu Paraense Emilio Goeldi, ser. Zool., 11(2):125-203.

Santos, S. M. L.; Glória, D. A.; Gomes, D. J., Santos-Filho, C.; Beasley, C. R. \& Tagliaro, C. H. 2003. Coletores artificiais para obtenção de turus (Bivalvia, Teredinidae). In: Congresso DE Ecologia do Brasil, $6^{\circ}$, Fortaleza. Anais... Fortaleza, Universidade Federal do Ceará. cap. 3, p.457-458.

Schetelma, R. \& Truit, R. V. 1954. Ecological factors related to the distribution of Bankia gouldi Bartsch in Chesapeake Bay. Chesapeake Biological Laboratory Publications 100: $1-31$.

Southwell, C. R. \& Bultman, J. D. 1971. Marine borer resistance of untreated woods over long periods of immersion in tropical waters. Biotropica 3(1):81-107.

Turner, R. D. 1966. A survey and illustrated catalogue of the Teredinidae (Mollusca: Bivalvia). Harvard, The Museum of Comparative Zoology. 265p.

1971. Identification of marine wood-boring molluses. In: Jones, E. B. G. \& Eltringham, S. K. eds. Marine borers, fungi and fouling organisms of wood. Paris, Organization for Economic Co-operation and Development. cap. 1, p.17-64. 1984. An overview of research on marine borers: past, progress and future direction. In: Costlow, J. D. \& Tipper, R. C. eds. Marine biodeterioration: an interdisciplinary study. Annapolis, Naval Institute. p.3-16.

Turner, R. D. \& Johnson, A .C. 1971. Biology of marine woodboring molluscs. In: Jones, E. B. G. \& Eltringham, S. K. eds. Marine borers, fungi and fouling organisms of wood. Paris, Organization for Economic Co-operation and Development. cap. 13, p.259-301.

Recebido em novembro de 2004. Aceito em novembro de 2005. ISSN 0073-4721

Artigo disponível em: www.scielo.br/isz 